\title{
Project Based Learning to Pose Reasoning Skills for Year 1 Pupil
}

\author{
Zahara Aziz ${ }^{1}$, Shamsinarhaliah Mohd Shamsuri ${ }^{1} \&$ Lily Damayanti ${ }^{1}$ \\ ${ }^{1}$ Faculty of Education, National University of Malaysia, Selangor, Malaysia \\ Correspondence: Zahara Aziz, Faculty of Education, National University of Malaysia, Selangor, Malaysia. Tel: \\ 16-3-8921-6259. E-mail: zaharaukm@yahoo.com
}

Received: March 4, 2013 Accepted: May 31, 2013 Online Published: July 19, 2013

doi:10.5539/res.v5n4p82

URL: http://dx.doi.org/10.5539/res.v5n4p82

\begin{abstract}
This article reports the results of a study on the implementation of the Project Based Learning (PBL) approach among Year 1 pupils at a selected school in Sepang, Selangor. This study was conducted to determine whether project based learning can pose reasoning skills for the Year 1 pupils in the topic of Plants in science subject. The study employed the collaborative action research approach design to pose reasoning skills among pupils. A total of 32 pupils in Year 1 had been selected as the respondents in this study. Teaching and learning activities had been carried out for 8 weeks, in which each learning session was held for one hour which followed the original class schedules. The study adopted the Three Phase Project Approach that was proposed by Katz \& Chard. The results showed that project based learning were able to draw pupils to be engaged better in their learning process. PBL can also help pupils raise their reasoning skills in learning.
\end{abstract}

Keywords: project based learning, reasoning skills, primary school, plan

\section{Introduction}

In 2011, the primary education system in Malaysia has gone through a form of education transformation from the Integrated Curriculum for Primary Schools (KBSR) to the Standard Curriculum for Primary Schools (KSSR). The transformation of the curriculum is based on KBSR integrated approach, a comprehensive individual development, opportunity, and quality education for all students and life-long education. Therefore, improvements have been made in KSSR to include three elements of creativity and innovation, entrepreneurship, and information technology as well as communications. Accordingly, KSSR emphasizes reasoning skills as well as skills in reading, writing and arithmetic (3M) to pursue the development of thinking, technology, economics and globalization that were compatible with the rapid development in the 21st century (BPK, 2012).

Reasoning skills is one of the essential skills in 21st century. Reasoning skills enable pupils to provide a causal and rational logic state to solve any problems. It can help pupils to understand the learning process. In addition, it can help pupils distinguish the good and the bad and also understand cause and effect. Pupils should be exposed to reasoning skills as at an early age, when their minds are already able to receive and process information. Reasoning skills will help pupils to promote exploration and generation of new ideas and will make pupils ready for any risk taking. Reasoning skills also enable pupils to think carefully and be flexible. Pupils with good reasoning skills will have the following characteristics: (1) being critical in thinking, creative and innovative, (2) being bold and wise, (3) want to know, (4) indicate thinking and are flexible, (5) working, (6) risk taking, (7) have foresight, and (8) making a comparison (BPK, 2012).

Bahagian Pembangunan Kurikulum or the Curriculum Development Centre (2010) defined reasoning skills as the use of logical reasoning to understand a situation or idea. This shows, teaching and learning involve reasoning skills which should be implemented in a planned, exciting manner and which challenges the imagination of pupils. Therefore, teachers should create a learning environment that can create curiosity of pupils who explore a topic of study more in-depth. When planning teaching and learning activities, teachers need to think of the need to developing pupil's intellectual, critical and creative thinking and also reasoning skills in order to solve problems and to make decisions.

Reasoning skills can be implemented in the teaching of all subjects and can be done either outside or inside of the classroom. By looking at the curriculum of primary schools in Malaysia, Science is one subject that is to make pupils develop reasoning skills. Science is important because it allows pupils to understand more about themselves and the environment and they should think critically and creatively about the implications it has on 
life in general. In addition, through learning Science pupils are able to develop their scientific and thinking skills (Poh, 2003).

All year one pupils learn about plants in their Science subject. By learning this topic, pupils not only need to know about plants, but they also need to analyse, create plant-based products and appreciate the plants around them. Learning about plants is significant in the primary schools because people will benefit substantially from learning about them. Plants are very useful especially in the field of medicine where WHO (World Health Organization) estimated that nearly 80 percent of people all over the world are still dependent on plants. They use plants especially for traditional medicines such as weeds, herbs and roots (Khan \& Singh, 2012). Nsolomo et al. (2003) states that the worlds of plants are constantly reviewed by people. Therefore, pupils must learn about plants as scientists are also interested to study the variety of plants in the world.The topic of plants will be more interesting when taught using effective procedures such as showing examples of trees around the school or pupils giving names of plants around their homes. In this matter, the Ministry of Education Malaysia has suggested a number of teaching and learning approaches. Among the approaches that can be implemented includes project-based learning approach (BPK, 2012).

\subsection{Project Based Learning}

Project-based learning (PBL) model is commonly used for education at the primary level (Katz \& Chard model, 2000). Katz and Chard's model of learning (PBL) involves three phases: (1) getting started, (2) doing fieldwork, and (3) concluding the project.

In the first phase, pupils and teachers need to take time to talk and to select the topics to be investigated. Topics may be proposed by the pupils or the teacher. Some criteria may be considered for choosing the topic. First, the topic should be closely related to pupils' daily experiences. At least some pupils should have sufficient knowledge of the topic that raises questions relating thereto. Second, in addition to basic literacy and numeracy skills, the topic has to be able to integrate in a wide range of subjects such as science, history, and language. The third consideration is that the selection of topics should be explored for at least within a week. Fourth, the topic should be more suitable for school examinations. For example, the study of the basic needs of animals and the comparative animals' life in extreme areas.

After having selected related topics, teachers usually start the learning activity by creating a web, or concept maps, to trigger the minds of pupils. Web-related topics and subtopics will be displayed and used to talk to get continuous feedback for project work. During preliminary discussions, the teacher and the pupils will suggest some questions to provide answers through inquiry. During the first phase of this project, pupils will also be trying to remember their previous experiences related to the topic.

The second phase consisted of investigations, which often involve field work to investigate the environment, objects, or events. This phase is the main phase of the project work. Pupils will carry out an investigation, give full attention, build models and perform various examinations carefully. Next, pupils will record the discovery, exploration, prediction, discuss and relate their new understanding.The third phase is the final phase in the PBL. This phase will determine pupils' understanding of the topic given. During this phase, pupils are required to present their findings. This includes the reports of the results in the form of discovery exhibits and artefacts, story telling or dramatic presentations.

\subsection{Teacher's Role in the Success of a Project-Based Learning}

A good organization of PBL is very challenging and requires a high commitment from the teachers. There are a lot of early preparations to do and teachers need to provide a relatively long period of time to conduct the project successfully. Teachers should play a greater role in the negotiations with the pupils than delivering the lessons. The other role of the teacher is to facilitate the process of PBL development by supervising and monitoring the pupils' progress. Teacher's observation of every pupil will help to identify other teaching activities required by the pupils. In addition, the teacher also needs to take note of the willingness of individuals or groups of pupils in the introduction of new knowledge and skills (Krogh \& Slentz, 2011).

In the early stages of schooling, teachers need to know how to carry out the PBL and need to get a clear picture of the operations of the project so that the learning activities go well although the process has to go through different activities. Children should be given a period of time which is sufficient for them to understand a concept and be able to associate new knowledge with existing knowledge to use any where around them to learn about life (Romarzila Omar \& Sharifah Nor Puteh, 2011). At this stage, the teacher plays the role of a consultant and let the pupil to organize the development of the investigation, encourage search for answers to the questions connected through deep observation as a result of discussions held. The timetable should be organized and 
arranged neatly so that the project can be carried out more smoothly. In addition, teachers can also give suggestions to the pupils to present the findings of their investigation. In the early stages of this school, the teacher plays an important role in documenting the experiences of pupils during the PBL run (Katz \& Chard, 2000).

\section{Method}

Integrated Curriculum for Primary Schools (KBSR) was transformed into the Standard Curriculum for Primary Schools (KSSR) in 2011. It affected many subjects in the primary education especially in implementation of reasoning skills in primary science as a new focus. KSSR suggested the project-based learning (PBL) as an approach in teaching and learning practice. Therefore, the main purpose of this study is to assess implementation of PBL approach to pose the reasoning skills among pupils. In this research, the topic of plants is selected for science subject. In addition, Katz \& Chard model is used as a teaching guide of PBL approach. In this study, the research question is focused on the PBL approach in the topic of plants in science subject to pose the reasoning skills in year one pupils.

\subsection{Research Design}

In conducting this research, collaborative action research approach is chosen because it involves a year one primary school teacher as the practitioner directly. The teacher can also provide a strong input from the current practical aspects of teaching practice. Researchers are involved as planners and observers in the class during the activity. Then the reflection will be done together between the teacher and the researchers. This will help both teacher and researchers to plan the right action later. Researchers who are involved as the observers during the class activity also obtain an overview of events and processes that occur in the classroom.

The action research design according to Kemmis and McTaggart (1988) can be viewed as a spiral cycle of reorganization planning, action, observation, and reflection which may then be followed by the next spiral cycle. Cycle can be seen in Figure 1.

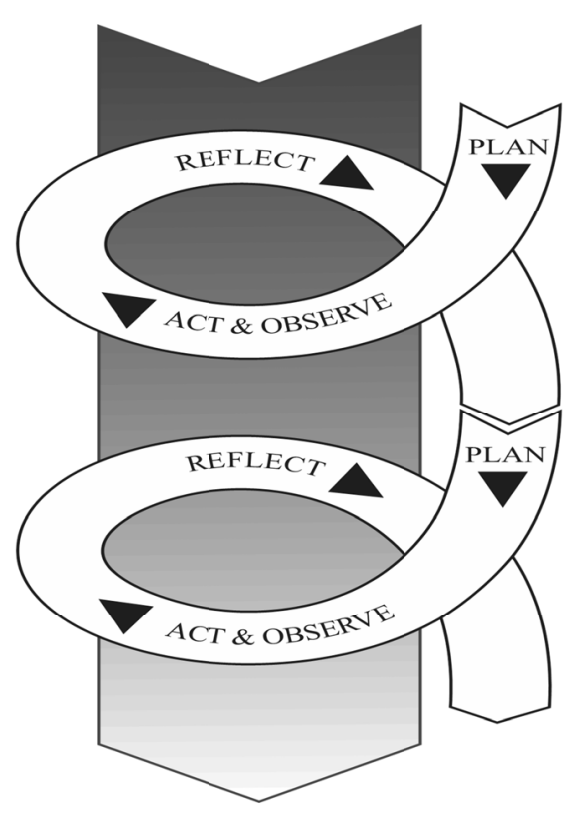

Figure 1. Model of actions research Kemmis and McTaggart

Based on the above diagram, conducted action research process involving a continuous cycle includes four stages, namely: 1) planning, 2) acting; 3) observing; 4) reflecting as in Table 1 
Table 1. The sequence of the action research cycle

\begin{tabular}{ll}
\hline Sequence & \multicolumn{1}{c}{ Explanation } \\
\hline Planning & $\begin{array}{l}\text { All of the requirements in the implementation of research, ranging from materials, lesson plans, } \\
\text { observation instruments, and so on should be fully prepared. At this level the risk occured by the } \\
\text { action will be taken as to allow the adaptation of the action. }\end{array}$ \\
Acting & $\begin{array}{l}\text { Intended action is the implementation of all the plans that have been made. Steps carried out by } \\
\text { the teacher must be suitable with the plan that has been made. }\end{array}$ \\
Observing & $\begin{array}{l}\text { Observations carried out on the action, influence on actions, conditions and constraints of action, } \\
\text { and other related issues. Data was collected by using instruments or other devices that have been } \\
\text { made accurately. Implementation of observation should not be done by teachers themselves, but } \\
\text { should involve collaborators. However, observer's collaborators do not have to intervene in the } \\
\text { ongoing learning process. }\end{array}$ \\
Reflecting & $\begin{array}{l}\text { Reflection is the process of remembering or reflecting the actions that have been performed and } \\
\text { recorded by the researcher in the observation sheet. In this process, problems and real constraints } \\
\text { of actions taken need to be understood. The reflection process involved the data from all entries } \\
\text { recorded by the collaborator, photos and comments were then analyzed to determine what action } \\
\text { hypothesis has been reached, or to plan for the next cycle. }\end{array}$ \\
\hline
\end{tabular}

Therefore, this study uses Kemmis and McTaggart's model of action research. This model is considered appropriate for the study whereby the researchers do observation and the teacher does the action at the same time. Researchers do the planning before the observation and action steps are carried out. Then researchers and the teacher will reflect on the action that has been implemented.

In this study, observations were made on a teacher and 32 pupils in a school during their science lesson. The teaching had been done 8 times in order to have a proper and valid study. The study implemented the PBL of Katz and Chard model in 3 phases. In the first phase pupils were drawing a web to find out the basic needs of plants. While in the second phase, pupils were doing project activities such as planting seeds, observing the seeds' development, and making comparisons of the plants growth between groups in the classroom. In the third phase, pupils' reasoning ability was challenged through doing presentations. During this phase, pupils analysed their findings and they had to give good reasons on what they had discovered and also compared their findings with the other groups. Here the researchers and the teacher would be able to measure the reasoning ability of the pupils by using the checklist.

\subsection{Study Sample}

In this study, respondents consisted of 32 year one pupils (13 males and 19 females). They were selected pupils from a primary school in Sepang, Selangor. Respondents were selected from the class that had problems with the reasoning skills, especially in the topic of Plant in the science subject.

\subsection{Research Instruments}

In this study, we used two research instruments of data collection, namely:

1. Checklists. It was used to observe the teaching and learning process. All teacher and pupils behaviours were recorded by the observers during the learning process in the classroom.

2. Photo. This will be used to validate the results obtained during the PBL process

\section{Results}

Project-based learning (PBL) approach used in teaching the topic of Plant in science was able to pose the reasoning skills among year one pupils. The activity was started by producing web topics. The pupils were required to make web topics on the topic of plants, where the content comes from various sources. The results showed that pupils doing this activity had fun. However, there were some groups that were still passive during the presentation of the web. Teacher also found that there were some pupils who did not find the information by themselves but they got the information by asking the group members. The findings are shown in Table 2 . 
Table 2. Checklist of web topic activity

\begin{tabular}{|c|c|c|c|c|c|c|}
\hline Item & $\begin{array}{l}\text { G- } \\
1\end{array}$ & $\begin{array}{l}\text { G- } \\
2\end{array}$ & $\begin{array}{l}\text { G- } \\
3\end{array}$ & $\begin{array}{l}\text { G- } \\
4\end{array}$ & $\begin{array}{l}\text { G- } \\
5\end{array}$ & $\begin{array}{l}\text { G- } \\
6\end{array}$ \\
\hline $\begin{array}{l}\text { Voluntarily involved in the search for information through the } \\
\text { material from the source }\end{array}$ & $\sqrt{ }$ & $\sqrt{ }$ & $\sqrt{ }$ & $\sqrt{ }$ & - & $\sqrt{ }$ \\
\hline Applying curiosity & $\sqrt{ }$ & $\sqrt{ }$ & $\sqrt{ }$ & - & $\sqrt{ }$ & - \\
\hline Collaborate with team members in producing web & - & $\sqrt{ }$ & - & $\sqrt{ }$ & $\sqrt{ }$ & $\sqrt{ }$ \\
\hline Can actively analyze results web finding topics in class & $\sqrt{ }$ & $\sqrt{ }$ & - & $\sqrt{ }$ & - & $\sqrt{ }$ \\
\hline
\end{tabular}

Based on the checklist in Table 2, there were two groups of pupils (group 3 and group 5) that were unable to analyse the web that had been formed. Members of the group could not explain the topics well based on the web. Previous studies showed that pupils obtained various benefits from PBL such as practical skills, problem solving, communication, self-management and was able to build good collaborative relationship (Brodi, 2008; Grant, 2009; Randler \& Hulde, 2007). However, the objective of the study had not been met on this first activity. Therefore, researchers felt the need to do the second activity in order to meet the objectives of the study which was to pose the pupils' reasoning skills in the project of Plants.

\subsection{Planting Activity}

This activity involved pupils to plant seeds in order to strengthen their understanding in the topic being discussed. Teacher asked pupils to provide the needs for planting the seeds by using their existing knowledge. This activity was able to stimulate pupils to be more interested in their learning. This could be seen when the pupils were getting excited to see the development of the seeds, especially when they were asked to put the planted seeds in two different places (inside and outside the classroom). All pupils were responsible for the seeds that had been planted and the processes of the development of the seeds were recorded. Pupils were asked to report the progress of the seeds and analyse the differences between the growth of the seeds in two different places. The findings can be seen in Table 3 .

Table 3. The checklist of planting seeds activity

\begin{tabular}{|c|c|c|c|c|c|c|}
\hline Item & G- 1 & G- 2 & G- 3 & G- 4 & G- 5 & G- 6 \\
\hline Voluntarily involved in the project & $\sqrt{ }$ & - & - & $\sqrt{ }$ & $\sqrt{ }$ & $\sqrt{ }$ \\
\hline Applying curiosity & $\sqrt{ }$ & $\sqrt{ }$ & $\sqrt{ }$ & - & $\sqrt{ }$ & - \\
\hline $\begin{array}{l}\text { Collaborate with team members in the development of seed } \\
\text { recorded }\end{array}$ & - & $\sqrt{ }$ & $\sqrt{ }$ & $\sqrt{ }$ & - & $\sqrt{ }$ \\
\hline Able to analyze the differences of plants placed in different places & $\sqrt{ }$ & $\sqrt{ }$ & $\sqrt{ }$ & $\sqrt{ }$ & $\sqrt{ }$ & $\sqrt{ }$ \\
\hline
\end{tabular}

Based on the checklist in Table 3, it was found that all groups of pupils had successfully analysed the differences of the plants that were being put at two different places. This indicated that the activity successfully posed reasoning skills among pupils. Therefore, PBL that was performed on samples was successful and has encouraged pupils' cognitive development through exploration of existing knowledge, which indirectly poses their reasoning skills. The finding in planting activity was compatible with the findings of previous studies which state that PBL allows the pupils' conceptual development and the pupils' comprehensive development change to be more positive. Through PBL approach was also found that the lessons learned and the development of pupils' skills would be permanent and was able to produce pupils who had high confidence level.

\section{Conclusion}

The overall findings of the study show that PBL is a very effective approach in teaching and learning activities, particularly in the samples studied. As PBL is pupils' centred learning, all pupils can be actively involved in learning activities that have been planned. In addition, this study also shows that the reasoning skills can be 
raised through the plant topic by using PBL approach. Mobley (2010) concluded reasoning skills as the ability to analyse information and solve problems in a literal sense, was involving basic knowledge about aspects of everyday life. It must be understood by the individual through a logical consequence of some action which occurs and has its impact on life. Reasoning skills involved in processing information and make inferences based on the perceptions of individuals (Exforsys, 2012). Capabilities in reasoning will allow individual understanding of ideas and concepts more clearly to make reasonable conclusions.

\section{References}

Brodi, J. (2008). Pelaksanaan Pembelajaran Berasaskan Projek: Satu Kajian Kes Teaching School, IPTAR. Jurnal Penyelidikan Pendidikan IPTAR, 99-119.

Bahagian Pembangunan Kurikulum (BPK). (2012). Buku Panduan Kemahiran Menaakul. Kementerian Pelajaran Malaysia,

Bahagian Pembangunan Kurikulum (BPK). (2010). Kurikulum Standard Sekolah Rendah Dunia Sains dan Teknologi Tahun 1 (p. 15). Kementerian Pelajaran Malaysia.

Bahagian Pembangunan Kurikulum (BPK). (2012). Hasrat KSSR. Retrieved September 23, 2012, from http://kssr.bpk.my/pengenalan/hasrat_kssr

Exforsys Inc-Self- Study Online Training. (2012). Thinking skill: Reasoning. Retrieved September 23, 2012, from http://www.exforsys.com/career-center/coreskills/thinking-skill-reasoning.html

Grant, J. (2009). Primary Knowledge, Medical Education and Consultant Expertise. Medical Education Journal, 22(3), 173-179. http://dx.doi.org/10.1111/j.1365-2923.1988.tb00002.x

Katz, L. G., \& Chard, S. C. (2000). Engaging Children's Mind: The Project Approach (2nd ed., p. 69). Stamford, CT. Ablex.

Kemmis, S., \& McTaggart, R. (1988). The Action Research Reader (3rd.). Victoria. Deakin University Press.

Khan, J. B., \& Singh, G. P. (2012). Ethno-Medicinal Diversity of Churu District Traditionally Used By Rural People. Indian Journal of Fundamental and Applied Life Sciences, 2(1), 109-114

Krogh, S. L., \& Slentz, K. L. (2011). Early Childhood Education: Yesterday, Today, and Tomorrow (Vol. 2). New York: Routledge.

Mobley, W. C. (2010). Role of Basic Science in Clinical Reasoning Education. AACP Meeting and Seminar, July 10-14, 2010.

Nsolomo, V. R., Mrecha, M. S., \& Magembhe, J. A. (2003). Effect of Acacia Xanthophloea Leachates on Seed Germination of Some Agricultural and Multipurpose Tree Crops. Journal of Tropical Forest Science, 7(3), 398-404.

Poh, S. H. (2003). Pedagogy of Science 2. Science Teaching \& Learning Strategies (p. 146). Kumpulan Budiman Sdn. Bhd.

Randler, C., \& Hulde, M. (2007). Hands-On Versus Teacher-Centred Experiments in Soil Ecology. Science And Technological Education Research, 25(3), 329-338. http://dx.doi.org/10.1080/02635140701535091

Romarzila, O., \& Sharifah, N. P. (2011). Pembelajaran Berasaskan Projek dalam Transformasi Kurikulum Pendidikan Prasekolah di Malaysia. International Seminar - Educational Comparison in Curriculum for Active Learning between Indonesia and Malaysia (pp. 785-794).

\section{Copyrights}

Copyright for this article is retained by the author(s), with first publication rights granted to the journal.

This is an open-access article distributed under the terms and conditions of the Creative Commons Attribution license (http://creativecommons.org/licenses/by/3.0/). 